\title{
Points of Progress: Ten Milestones Paving the TMS Foundation's Path to Growth
}

\section{Lynne Robinson}

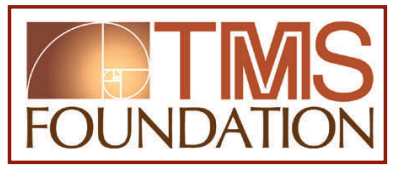

\section{TMS Foundation: growth through giving}

This regular JOM feature provides updates on TMS Foundation activities, as well as news on opportunities for TMS Foundation support and engagement. Visit the Foundation website at www.TMSFoundation.org to learn more.

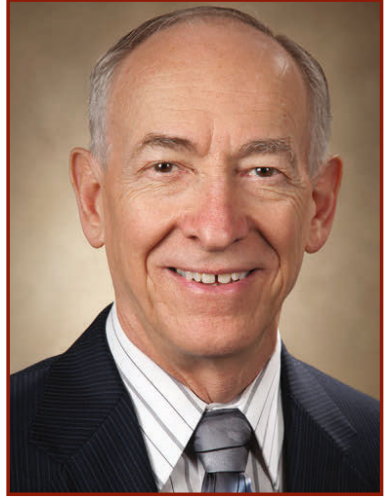

Garry W. Warren
Garry W. Warren, TMS Foundation Board of Trustees Chair, had a very good story to tell during the Donor Appreciation Dinner held during the TMS 2017 Annual Meeting \& Exhibition (TMS2017) on February 26 in San Diego.

2016 marked the Foundation's fourth consecutive year of steady growth in contributions and donors, with $\$ 551,791$ secured through fulfilled and new pledges, a gift from TMS, unrestricted and restricted donations, and several fundraisers. "I think we are beginning to reap the rewards from our revitalization efforts that were launched in 2013," said Warren. "TMS Members are much more aware of the Foundation and the initiatives that it supports. I hope and expect that this growth will continue."

While positive year-end numbers grab

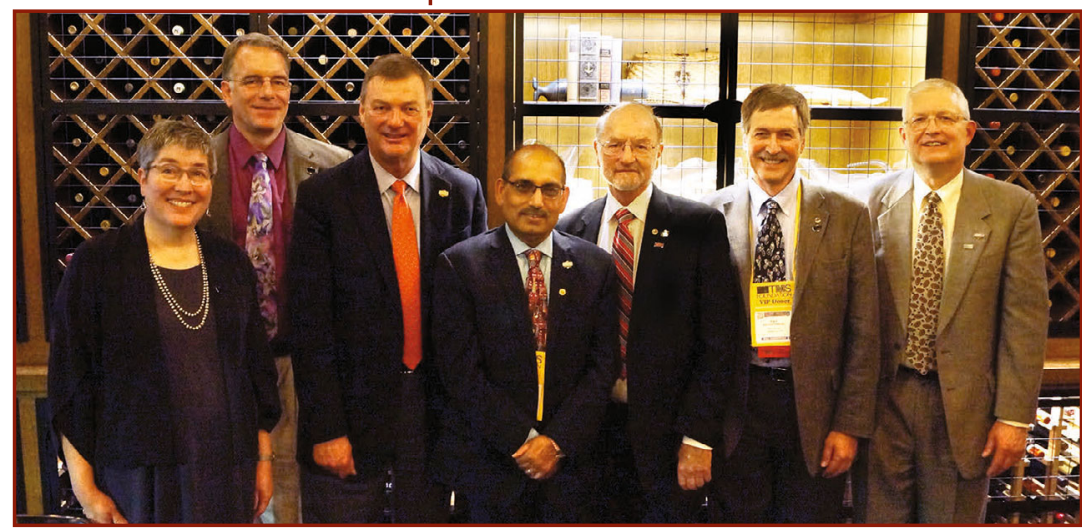

The TMS Foundation recognized a number of new honorific society members at its Donor Appreciation Dinner held during TMS2017. Pictured from left: Elizabeth Holm (Titanium Society), Carl Cady (Titanium Society), Jeffrey Wadsworth (Diamond Society), Brajendra Mishra (Titanium Society), Stanley Howard (Titanium Society), Ray Peterson (Silver Society). and David DeYoung (Silver Society.) Not pictured, but inducted into the Foundation's new Titanium Society are Joseph Defilippi, Gordon Geiger, Lionel Kimerling, Kenneth Kinsman, and William Wagstaff (deceased).

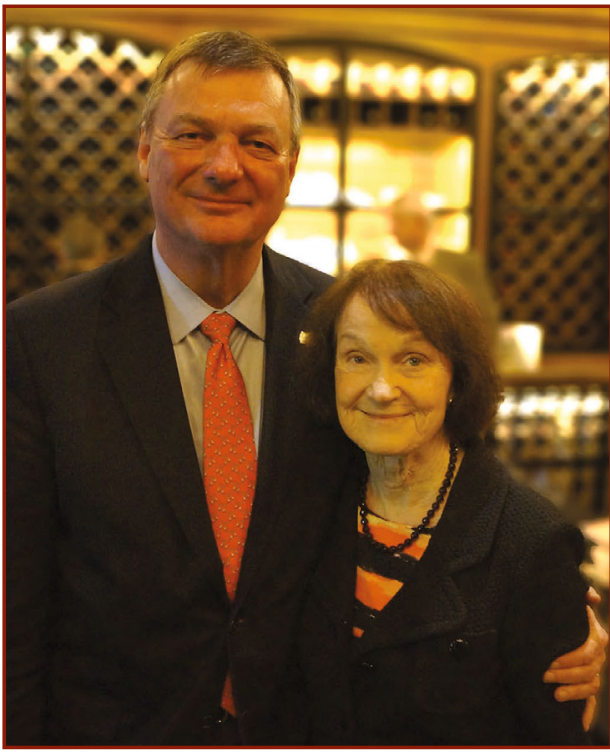

Jeffrey Wadsworth, Battelle chief executive officer and president and 2000 TMS

Fellow, and his wife, Geraldine McCulley Wadsworth, were honored as the TMS Foundation's newest Diamond Society members.

headlines, the careful, impactful steps leading to that goal also warrant attention and thanks to those who made them possible. What follows is a countdown of ten achievements to celebrate from the TMS Foundation's last eventful year, with a look ahead to future developments.

\section{2016 Annual Appeal Aims High}

For the first time in its history, The TMS Foundation formally announced a target goal for its year end Annual Appeal, and it was quite an ambitious one $-\$ 100,000$ in individual donations. To provide incentive 


\section{TMS Foundation Board of Trustees}

Chair:

Garry W. Warren

Professor Emeritus,

University of Alabama

Executive Committee

Representative:

Stanley M. Howard

Professor,

South Dakota School of

Mines and Technology

Trustees:

Viola L. Acoff

Associate Dean,

University of Alabama

\section{Carl M. Cady}

Technical Staff Member,

Los Alamos National

Laboratory

\section{Hani Henein}

Professor,

University of Alberta

Edward D. Herderick

Global Sales Leader,

Portables NDT,

GE Oil and Gas

\section{Elizabeth A. Holm}

Professor,

Carnegie Mellon

University

\section{Ray D. Peterson}

Director, Technology,

Real Alloy

David A. Shifler

Program Officer

Office of Naval Research

\section{Secretary:}

James J. Robinson

TMS Executive Director to reach that goal, Martin and Lucinda

Glicksman and Robert and Robyn Wagoner took the lead, along with Garry Warren and Stanley M. Howard, to establish a $\$ 30,000$ match to the first $\$ 30,000$ raised in the campaign.

TMS members rose to the challenge, not only securing the $\$ 30,000$ match but also getting very close to the goal, with $\$ 91,660$ raised by the time the 2016 Annual Appeal campaign closed on December 31.

\section{Division Scholarships Double Their Impact}

Through the generous support of Jeffrey Wadsworth, chief executive officer and president of Battelle and a 2000 TMS Fellow, TMS division scholarships have doubled in monetary value to their student recipients. Starting with awards conferred in 2018, each undergraduate division scholarship will be matched, dollar for dollar, through the Battelle Matching Scholarship Program. Additionally, every student who receives a Battelle Matching Scholarship will also receive a Battelle Materials Graduate Student Scholarship when the student continues advanced studies in a materials-related field.

\section{c TMS Awards First Kaufman CALPHAD Scholarship}

Zach Jensen, University of WisconsinMadison, was recognized as the first recipient of the Kaufman CALPHAD Scholarship at TMS2017. Established through an endowment from CALPHAD and the efforts of Zi-Kui Liu, CALPHAD Inc. president and professor, The Pennsylvania State University, the scholarship recognizes the contributions of the late Lawrence "Larry" Kaufman to computational thermodynamics and its applications.

\section{Ongoing Efforts Advance Diversity and Inclusion}

TMS celebrated the life and impact of Frank Crossley - the first African American to earn a Ph.D. in metallurgy and a TMS member since 1947-by organizing the 2nd Summit on Diversity in the Minerals, Metals, and Materials Professions (DMMM2) in his honor. A highlight of that event was the presentation of the inaugural TMS Frank Crossley Diversity Award to Carolyn Hansson, professor, University of Waterloo, and a 1997 TMS Fellow. Established by Jeffrey Wadsworth, and his wife, Geraldine McCulley Wadsworth, the Frank Crossley Award annually honors an individual who has "overcome personal, professional, educational, cultural or institutional adversity to pursue a career in minerals, metals, and/ or materials." It joins the TMS Ellen Swallow Richards Diversity Award, also established by the Wadsworths, to highlight the examples, actions, and achievements of pioneering role models in diversity as a means of inspiring others in their career journeys, while motivating action to create a more inclusive professional community.

\section{The TMS Community Celebrates Julia and Johannes Weertman}

Julia and Johannes Weertman have touched the lives of countless students and professionals through their generosity of spirit and intellect. They have also both contributed significantly to the body of knowledge of physical metallurgy and recognition of materials science and engineering as a discipline. Along with the Department of Materials Science and Engineering and the McCormick School of Engineering and Applied Sciences at Northwestern University, a group of more than 40 colleagues and friends of the Weertmans offered a lasting gesture of thanks by establishing a fund to rename and enhance the TMS Educator Award in their honor. Starting in 2018, the Julia and Johannes Weertman Educator Award will now include a medallion, a TMS annual meeting registration waiver, and a $\$ 1,500$ stipend for travel to the TMS annual meeting where the recipient will accept the award.

\section{New Award Honors the Legacy of Oleg D. Sherby}

By advancing scientific progress on ultrahigh carbon steels, Oleg Sherby was able to reclaim a piece of metallurgy's past - the art of forging Damascus steel and other ancient weapons. Jeffrey Wadsworth collaborated with Sherby on much of this work in a partnership that started when 
Wadsworth was a postdoctoral researcher with Sherby at Stanford University. To honor his mentor and friend, Wadsworth established a fund to support the new Oleg D. Sherby Award with the intent of recognizing individuals who are building on Sherby's scientific legacy by having a major impact on the understanding of the behavior of materials at high temperature. Recipients will receive a medal and $\$ 5,000$ cash prize. The first award will be conferred at the TMS 2018 Annual Meeting \& Exhibition, March 11-15, in Phoenix, Arizona.

\section{A. Precious Metals Recognize Precious Donors}

The TMS Foundation welcomed and thanked the first class of members to its Titanium Society at the TMS Foundation Donor Appreciation Dinner at TMS2017. Established in 2016, this new honorific giving society recognizes donors with lifetime contributions totaling $\$ 10,000$ to $\$ 19,999$. Another new donor recognition opportunity is the TMS Foundation Platinum Society, which honors those making lifetime contributions totaling $\$ 50,000$ to $\$ 99,999$.

\section{Q Diamond Society Adds New Member}

Jeffrey Wadsworth and Geraldine McCulley Wadsworth are familiar names on this list. Their commitment to supporting an array of TMS initiatives through the TMS Foundation was formally recognized with their induction into the Diamond Society, the Foundation's pinnacle honorific society for those contributing $\$ 100,000$ more over a lifetime. They join Martin and Lucinda Glicksman, the Foundation's inaugural Diamond Society members.

\section{D) New Leadership Joins Board of Trustees}

"One of the most important things that the TMS Foundation Board of Trustees can do is to ask members to serve who are recognized and highly regarded by our TMS community," commented Garry Warren. He noted that the Board's newest trustees - Ray D. Peterson, Director, Technology, Real Alloy and Viola L. Acoff, associate dean for undergraduate and graduate programs, The University

of Alabama

College of

Engineeringare exceptionally well qualified for this responsibility. (See sidebar article.)

"Serving on the Board requires time and dedication and both Ray and Viola have demonstrated that they care about TMS and the Foundation and are willing to give their full support to our work," Warren said.

\section{0 The TMS Foundation Family Is Growing-A Lot}

A few short years ago, the list of annual donors to the TMS Foundation couldn't fill one page in JOM. With the 2016 TMS Foundation Honor Roll presented on the following pages of this article, it's clear that support for the Foundation is following a strong, clear growth pattern. Warren is pleased with the progress and appreciative of the commitment that the TMS membership has shown to the Foundation's continued success. He also acknowledges that there is still a great deal of work ahead. "We have now put our fundraising efforts on a good path," he said, "but I think our greatest challenge is to keep our foot on the accelerator and not to become complacent."



Stanley Howard (left), 2016 TMS President and TMS Foundation

Trustee, receives his commemorative pin and thanks for being inducted into the Foundation's new Titanium Society from Garry Warren (right), TMS Foundation Board of Trustees Chair and 2011 TMS President. Antoine Allanore (center) 2011

Extraction \& Processing

Division Young Leader Professional Development Award recipient, spoke at the TMS2017 Donor

Appreciation Dinner about the impact that the Foundation has made on his career.

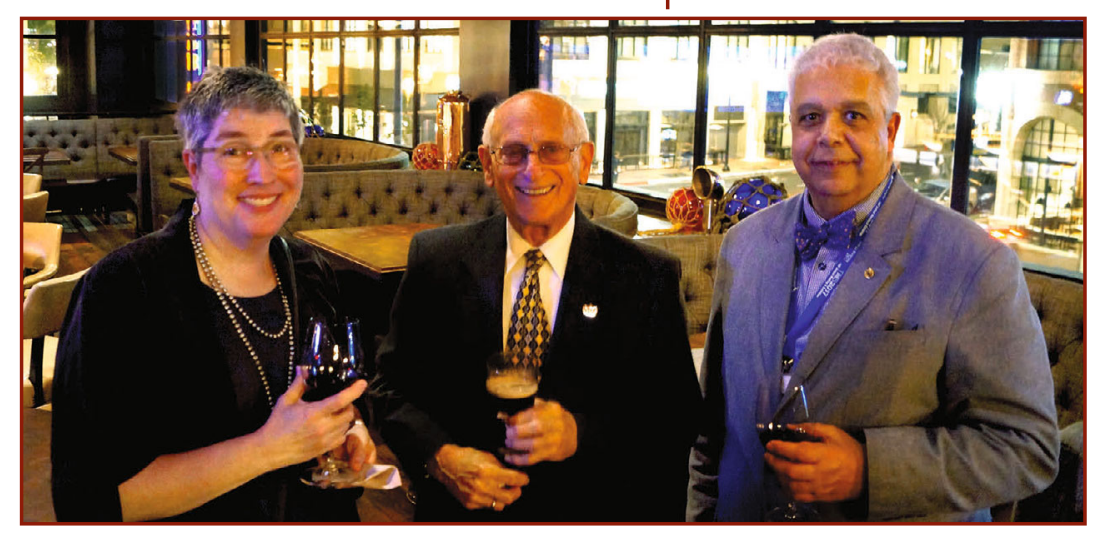

The TMS Foundation is fortunate that some of TMS's most distinguished leaders are so deeply committed to its growth and ongoing service to the professional community. Pictured at the TMS2017 Donor Appreciation Dinner are (from left): Elizabeth A. Holm, 2013 TMS President and TMS Foundation

Trustee (Titanium Society); Martin E. Glicksman, 1994 TMS Fellow and inaugural TMS Foundation Diamond Society member; Hani Henein, 2014 TMS President and TMS Foundation Trustee (Silver Society). 


\section{The 2016 TMS Foundation Honor Roll}

The TMS Foundation thanks the following TMS members and friends for their generous support in 2016. Their gifts are critical to the success of current and future TMS Foundation programs, including student scholarships and professional development support of early career minerals, metals, and materials scientists and engineers.

To secure your place on the 2017 TMS Foundation Honor Roll, visit
www.TMSFoundation.org to make an online donation. Contact Mary Samsa, TMS Foundation \& Public Affairs Manager at msamsa@tms .org with questions or for information on additional donation options.

\section{Lifetime Giving Honorific Societies}

Diamond Society $\mathbf{( \$ 1 0 0 , 0 0 0}$ or more)

Martin E. and Lucinda Glicksman

Jeffrey Wadsworth and Geraldine

McCulley Wadsworth

Platinum Society $\mathbf{( \$ 5 0 , 0 0 0}$ to $\$ \mathbf{9 9 , 9 9 9 )}$

New in 2016. Future members to come.

Gold Society (\$20,000 to \$49,999)

Diran and Seta Apelian

Om P. Arora (deceased)

Rob and Robyn Wagoner

Garry W. Warren

\author{
Titanium Society $(\mathbf{\$ 1 0 , 0 0 0}$ to $\$ \mathbf{1 9 , 9 9 9 )}$ \\ Carl M. Cady \\ Joseph and Bonnie Defilippi \\ Gordon H. Geiger \\ Elizabeth Holm and David Crockett \\ Stan and Carol Howard \\ Lionel and Linda Kimerling \\ Kenneth R. Kinsman \\ Brajendra and Deepa Mishra \\ William G. Wagstaff (deceased) \\ Silver Society $(\mathbf{\$ 5 , 0 0 0}$ to $\$ \mathbf{\$ 9 , 9 9 9 )}$ \\ Viola L. Acoff \\ Cynthia K. Belt \\ David and Joan DeYoung
}

\author{
Hani Henein \\ Edward D. and Michelle A. Herderick \\ Gregory and Joy Hildeman \\ Marc A. Meyers \\ Ronald E. Miller \\ Harold W. Paxton \\ Ray D. Peterson \\ James and Lynne Robinson \\ Alexander and Angela Scott \\ David Shifler in memory of Robert B. \\ Pond Sr. \\ King-Ning Tu \\ Patrice and Michèle Turchi \\ Frank E. Wagstaff \\ Robert B. Wagstaff
}

\section{TMS Foundation Welcomes New Trustees}

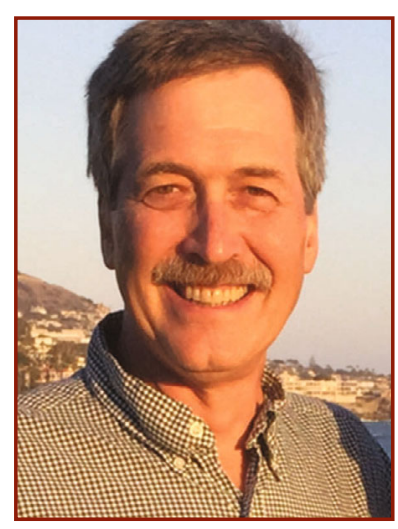

Ray D. Peterson

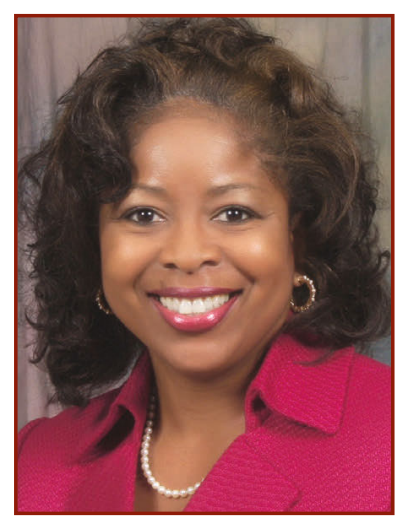

Viola L. Acoff
Ray D. Peterson, Director, Technology, Real Alloy and Viola L. Acoff, associate dean for undergraduate and graduate programs, The University of Alabama College of Engineering, were officially installed as the newest members of the TMS Foundation's Board of Trustees at the TMS 2017 Annual Meeting \& Exhibition.

The 2009 TMS President, Peterson noted that he is pleased to be part of the "new energy within the Foundation" and is looking forward to helping it achieve its goals. "For many years, the Foundation had been operating at a low level, but recently the amount of energy being put into the Foundation and the results produced have skyrocketed," he said. "I want to see the Foundation succeed, because I believe in the Foundation's goals of helping students and young professionals."

"Until recently, many TMS members were not aware of the Foundation. There still may be some members who are not aware of what we are trying to accomplish," Peterson continued. "I want to help get the word out to our members so that each of them can contribute in whatever way they can."

"We have all personally benefitted from our professional life and our affiliation with TMS," Peterson further commented. "I believe it is critical that we help our younger members just as we were helped earlier in our careers. The Foundation gives us a method to easily support our younger members through the programs it sponsors.

Acoff notes that she can speak from experience about the value of supporting the TMS Foundation's programs that support early career professionals. "The TMS Foundation has played a significant role in my development since the start of my career," she said. "Nearly 20 years ago, I was selected as one of the TMS Young Leaders Interns (now Young Leaders Professional Development Award.). This gave me the opportunity to learn more about the inner workings of TMS and the opportunities the TMS Foundation provides for students and professionals in the minerals, metals, and materials field. Since that time, I have seen my students receive various TMS scholarships, travel grants, and awards for best poster and best paper, all of which were made possible by the TMS Foundation."

"I also that think it is awesome that the TMS Foundation supports awards that recognize TMS members who play a vital role in increasing diversity and inclusion in the minerals, metals, and materials field," commented Acoff, who is the inaugural Ellen Swallow Richards Diversity Award recipient. "Serving on the TMS Foundation Board of Trustees is a way for me to pay forward the benefits I received from the TMS Foundation."

"I am looking forward to introducing others to the wonderful opportunities that are provided by the TMS Foundation so that they will be compelled, just as I was, to give to it." 


\section{Annual Donors}

Foundation Leader $\mathbf{( \$ 2 , 5 0 0}$ or more)

Battelle

Carl M. Cady

Martin E. and Lucinda Glicksman

Elizabeth Holm and David Crockett

Stanley and Carol Howard

Kenneth R. Kinsman

Lawrence Livermore National Laboratory

Marc A. Meyers

Brajendra and Deepa Mishra

Northwestern University

Gregory B. Olson and Jane E. Black

James and Lynne Robinson

Robert D. and Mary C. Shull

Patrice and Michèle Turchi

Jeffrey Wadsworth and Geraldine

McCulley Wadsworth

Rob and Robyn Wagoner

Garry W. Warren

Foundation Founder $\mathbf{( \$ 1 , 0 0 0}$ to $\$ \mathbf{2 , 4 9 9 )}$

The American Institute of Mining,

Metallurgical, and Petroleum

Engineers (AIME)

Corbett C. Battaile

Cynthia K. Belt

David L. Bourell

Jonathan A. Dantzig

Joseph D. and Bonnie Defilippi

David and Joan DeYoung

George T. Gray III

Sossina M. Haile

Hani Henein

Edward D. and Michelle A. Herderick

George Krauss

David and Diane Laughlin

Thaddeus B. Massalski

Ronald E. Miller

Tai-Gang Nieh

Harold W. Paxton

Ray D. Peterson

Mark Ratner

Alexander and Angela Scott

David N. and Rose Seidman

David Shifler in memory of Robert B.

Pond Sr.

Samuel I. Stupp and Devora Grynspan

John M. Torkelson

King-Ning Tu

Foundation Builder (\$500 to \$999)

Antoine Allanore

Anonymous Donor

ASM Boston Chapter in memory of Larry

Kaufman

Edouard Asselin

Shuanglin Chen

Yip-Wah Chung and Metty S. Poei

Buckley Crist Jr. and Susan B. Crist

Ray and Mary Decker
Dennis M. Dimiduk

Carolyn M. Hansson

Kevin and Maria Oliva Hemker

Lincoln J. Lauhon and Maureen K. Bolon

Enrique J. Lavernia

Peter K. Liaw and Jin Chwin Liaw

Zi-Kui Liu

Ramulu Mamidala

David and Diane Matlock

Tresa M. Pollock in honor of Ali Argon

Robert B. Wagstaff

Wagstaff Inc.

Foundation Provider (\$250 to \$499)

John E. Allison

Raymundo Arróyave

Brad L. Boyce

Eric N. Brown

James A. Clum

Vinayak P. Dravid

James C. Foley

Joy H. Forsmark

Ronald Gibala

Siegfried S. Hecker

Mary C. Juhas

Jamie J. Kruzic

Amanda K. Long

Christina Elizabeth Meskers

Rajiv S. Mishra

Mark Stoudt and Carelyn Campbell

Joseph F. Thomas Jr.

Bruce W. Wessels

Steven J. Zinkle

Foundation Ambassador (\$100 to \$249)

Anonymous Donor, care of Praxair Foundation
Alan J. Ardell

Ali S. Argon

James Ault

Ian Baker

Thomas P. Battle

Behzad B. Bavarian

Thomas R. Bieler

John C. Bierlein

William J. Boettinger

Douglas Burkes

Kimberly and Patrick Cannon

R.P.H. Chang and Bennie C. Chang

Indrajit Charit

Richard E. Cole

Megan J. Cordill

Stan A. David

Jaroslaw W. Drelich

Jonathan D. Emery and Renee L. Emery

James W. Evans

Jeffrey W. Fergus

Joel Filner

Alois J. Franke

Brent T. Fultz

Gordon H. Geiger

Joseph M. Giglio

John A.S. Green

Xiaofei Guan

Douglas C. Haag

William L. Hamm Jr.

Leonard Harris

Ola Harrysson

Jeffrey A. Hawk

Robert W. Hayes

Richard W. Hertzberg

John P. Hirth

Lee E. Hoffman

\section{Andrea Holland Joins the Foundation Team}

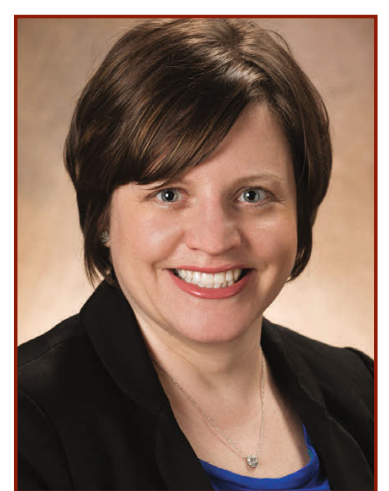

Andrea Holland

Andrea Holland walked into the bustling halls of TMS2017 just four short days after she started her new position as the TMS Foundation development manager. She quickly discovered that TMS members are an engaging, committed family of professionals.

"I'm looking forward to building partnerships with our volunteers and donors and ultimately connecting their passion for TMS with the Foundation's needs," she said. "The quick interactions I had at the annual meeting showed me that this is very possible."

A Certified Fundraising Executive, Holland brings more than 15 years of experience to TMS and has generated more than $\$ 45$ million in charitable revenue for a variety of non-profit institutions over that time. These include Northwestern University, The Ohio University, Wichita State University, Allegheny College, the Phi Theta Kappa Foundation, and the American Cancer Society.

"From the beginning, the Board of Trustees recognized that a dedicated, professional fundraiser on staff would be a great benefit," said Garry Warren, TMS Foundation Board of Trustees Chair. "With Andrea's experience and expertise, I anticipate new fundraising initiatives that will help us grow the unrestricted funds we need to support any new activities." 
William P. Imrie

Derk Joester

Sandra Kaufman in memory of Larry Kaufman

Peter L. Kern

Carl C. Koch

Carlos G. Levi

John J. Lewandowski

James M. Lommel

Jyotirmoy Mazumder

Terry R. McNelley

Thomas W. Montemarano

Neville R. Moody

John W. Morris Jr.

Benjamin Morrow and

Clarissa Yablinsky

Jagdish Narayan

Eric A. Nyberg

Susumu Okabe

Elsa Olivetti

Matthew G. Osborne

Uday Bhanu Pal

Eun Soo Park

Michael W. Perkins

Norbert L. Piret

Robert A. Rapp

Ramana G. Reddy

David G. Robertson

James Rondinelli

Herman S. Rosenbaum

Justin and Erin Scott

James L. Smialek

Raymond L. Smith

Douglas Spearot

Joseph Tunick Strauss

Dilip K. Subramanyam

Masao Suzuki

Dan J. Thoma

Arthur P. Turner

Pello Uranga

Dirk E. Verhulst

Richard M. Waterstrat

Julia and Johannes Weertman
Jean M. Winterbottom

in memory of Walter

Winterbottom

Yuntian T. Zhu

Foundation Patron

(\$25 to \$99)

Patrick M. Afenya

Yousuf Ali Mohammed AlFarsi

Alethea Backensto in memory of Arthur B. Backensto Jr.

Roy Baguley

David F. Bahr

Andrew Bain

Anthony John Barnes

David L. Baty

Knut Bauer-Partenheimer

Adi Ben-Artzy

Christine J. Beyke

George J. Binczewski

Michael P. Brady

Daniel C. Bufford

Carelyn E. Campbell

John E. Carsley

Jennifer L.W. Carter

Adrian V. Catalina

Ellen K. Cerreta

Nitin Chandola

Joseph Chieu

Julie A. Christodoulou

Leo Christodoulou

Harold R. Clark

Jacob Crane

Mahesh N. Darji

Tim Darling

Nimai C. Datta

Roberto R. De Avillez

Christian Decaillet

Steven L. Dedmon

Alfredo Oscar Del Campo

Alain Dery

\title{
Be a Part of the TMS Foundation Success Story
}

\author{
Donate Online: Visit www.TMSFoundation.org/ \\ Contribute.
}

Mail a Check: TMS Foundation, 5700 Corporate Drive, Suite 750, Pittsburgh, PA 15237.

Employer Match: Register The Minerals, Metals \& Materials Society for an employer match with your company. TMS (EIN \#: 25-1484913) is a qualified 501(c)(3) tax-exempt organization.

Give Us a Call: Contact Mary Samsa, TMS Foundation \& Public Affairs Manager at 724-814-3130 or msamsa@tms.org for information on donation options or to donate by phone.

Remi Dingreville

George J. Dormer

Junji Eguchi

Walter E. Elkington

Jerry F. English in memory of Alan T. English

Michael G. Fahrmann

Saryu Jindal Fensin

John W. Fernihough

Everaldo Ferreyra

Robert D. Field

John E. Flinn

Stephen M. Foiles

George D. Fulford

David Furrer

Timothy P. Gabb

Rajendra M. Gandhi

Mark T. Gbillah

Anthony F. Giamei

Douglas E. Gobeski

Ashok Kumar Gogia

William M. Goldberger

Richard E. Grace

Mustafa Guclu

Frederick R. Hafner

Dietmar Helm

Brooks Henderson

David A. Hunt Jr.

Nicholas W. Hutchinson

Margaret M. Hyland

Mihaiela Isac

Melvin R. Jackson

C. Shashank Kaira

Pat W. Kingman

Ralph C. Kirby

Randolph E. Kirchain

Sanji Kitaoka

Dariusz Kopycinski

Hanlie Kotze

Niinobe Kouichi

Dileep Kumar C J

Howard R. Last

Rodolfo S. Lazo Davila

Jae-chun Lee

Pei Yong Li

Yi Liu

Xingbo Liu

Joao Luiz Lopes Rezende

Vazquez B. Lucio

Stefan Luidold

Laurence D. Marks

Koichiro Mashio

Paul Mason

Suveen N. Mathaudhu

Jan W. Matousek

Alexander McLean

Antonio Jose Melendez

Ramirez

Masahiro Michino

Daniel B. Miracle

Arthur E. Morris
Carol E. Moyer

George T. Murray

Roger Jagdish Narayan

Neale R. Neelameggham

Sergey B. Novichkov

Kenneth M. O'Connor

Funsho K. Ojebuoboh

Soobhankar Pati

Frank E. Pfefferkorn

Paul D. Prichard

V. Ramachandran

Ashwin Ramasubramaniam

Ramesh C. Rao

Bhakta B. Rath

Charles E.C. Rense

Lewis Reynolds

Nolan E. Richards

Michael Roesner-Kuhn

Kirk Alan Rogers

Mark Alan Rosenzweig

Krishnan K. Sankaran

Thomas Schenk

Michael C. Schneller

James Schroth

Philip L. Sibrell

Eugene A. Silva

Ogle R. Singleton

Ernest J. Sirois

Bradford K. Slocum

Beata A. Smyrak

Joalet D. Steenkamp

Robert L. Stephens

Malcolm Stocks

Chantal K. Sudbrack

Dion J. Sunderland

Tohru Takahashi

John M. Tartaglia

Peter-Hans Ter Weer

Jacques P. Thiriar

Carlos N. Tome

Stewart W. Towle

Dallas R. Trinkle

Kinga Angelika Unocic

Paul R. Van Houtte

Heather M. Volz

Tadao Watanabe

Trevor J. Watt

David O. Welch

Harovel Wheat

Glenn G. Whiteside

Matthew A. Willard and

Family

David B. Witkin

Patrick Woolsey

Guang Xu

Zhihao Yao

Jien-Wei Yeh

Charles Fred Yolton

Mingming Zhang

Wenyan Zhang 